\title{
楆
}

\section{Kyk, beleef of luister?}

\section{Spiritualiteit in die Psalms in die lig van Psalm 1 en 2}

\author{
J.L. Helberg \\ Skool vir Bybelwetenskappe en Bybeltale \\ Potchefstroomkampus \\ Noordwes-Universiteit \\ POTCHEFSTROOM \\ E-pos: jaapjlh@absamail.co.za
}

\begin{abstract}
Look, experience or listen? Spirituality in the Psalms in the light of Psalm 1 and 2

A few approaches regarding spirituality are highlighted. An investigation is then made about what the psalms say regarding issues such as the following: in the training school of the Torah (Psalm 1), experience and creativity, vigour, complaint and praise, spirituality and enmity. Psalms 1 and 2, approached as introduction to the Psalter, show that the Torah (Law/Word) of the Lord occupies an all-important place in spirituality. Spirituality has especially to do with instruction and relations. Trust, joy and amazement combined with reforming selfdiscovery play an important role. One must commune with the Torah, and thus with God and also with one's neighbour by listening and being involved. One must comply with the Torah in practical life and actively love one's neighbour, especially the needy.
\end{abstract}

\section{Opsomming}

Kyk, beleef of luister? Spiritualiteit in die Psalms in die lig van Psalm 1 en 2

Enkele opvattings oor spiritualiteit word uitgelig. Daarna word ondersoek wat die psalms oor sake soos die volgende sê: in die leerskool van die Tora (Psalm 1), belewing en kreatiwiteit, kragdadigheid, klaging en lofsegging, spiritualiteit en vyandskap. Psalm 1 en 2, benader as inleiding tot die psalmbundel, wys dat die Tora (Wet/Woord) van die Here 'n allesoorheersende plek in spiritualiteit het. Spiritualiteit het veral met onderrig en met verhoudings te doen. Vertroue, vreugde en verwondering, gepaard met reformerende selfontdekking, speel 
hierin 'n belangrike rol. 'n Mens moet luisterend en betrokke omgaan met die Tora en dus met God en jou naaste. Jy moet die Tora in die praktyk nakom en die regverdiges daadwerklik liefhê, veral die hulpeloses.

\section{Inleiding}

Van der Linde (1960:119; 1961:234) assosieer spiritualiteit met die Rooms Katolieke teologie as die wyse waarop die vita spiritualis, die geestelike lewe, vorm kry. Die Christelike religie is die volle teendeel van die mistiek. Eersgenoemde gaan die weg van bemiddeling en van die persoonlike Middelaar op en nie van die mistieke onmiddellikheid nie, ook nie die weg van wêreldmyding nie. By die Puriteine en Piëtiste kom iets van spiritualiteit aan die orde by die "praktyk van die godsaligheid". Volgens Wakefield (1983:363) verskil Katolieke en Protestantse spiritualiteit daarin dat "the one will lay more emphasis in our own effort towards God, of union consummating purgation and illumination, whereas for the other all is of God's justifying mercy and begins the mystical union, which is the first work of saving grace in our hearts". Die reformatore beroep hulle ook op die kerkvader Augustinus. Volgens Bonner (1983:3334) het Augustinus sterk leiding oor spiritualiteit gegee. Spiritualiteit sluit by hom altyd 'n intellektuele element in. Al beheers liefde die teologie van Augustinus "the ascent to God is a mental, as well as affective and emotional, journey". Meditasie en filosofiese vraagstelling rus vir Augustinus op die studie van die Skrif.

Die term spiritualiteit word in ons tyd meer en meer gebruik. Volgens De Villiers $(1999: 416,418)$ het spiritualiteit een van die beheersende tendense in die moderne samelewing en teologie geword. In baie universiteite vorm dit deel van die standaard kurrikulum. Die tendens is volgens hom weg van ' $n$ blote indiwiduele na meerdere kommunale vorms van spiritualiteit.

Spiritualiteit het verskillende kante en selfs inhoude, afhangende wat 'n mens se uitgangspunt daaromtrent is (vgl. Wiethaus, 1996:402419 vir 'n indringende bespreking van verskillende huidige benaderings van die begrip). Volgens sommige teoloë is daar verskillende teologiese vorms van spiritualiteit in die Bybel. Veral in die postmoderne tyd is die benadering sterk dat daar nie net een norm vir die lewe is nie, maar verskillende norme volgens die uitgangspunte van verskillende persone. Verder is daar 'n reaksie teen die verstand as sogenaamde uiterlike en objektiewe norm. Daar word meer bevrediging van belewing verwag. 
Die televisie met sy sigbare aanbieding van dinge en gebeurtenisse, voed die behoefte aan ' $n$ meer sigbare beoefening en aanbieding van godsdiens. Samehangend hiermee is daar ook 'n behoefte aan uiterlike belewenis of 'n meer gevoelsmatige godsdiensbeoefening. By baie wek dit egter ' $n$ behoefte aan ' $n$ minder uitwendige en ' $n$ meer innerlike, onsigbare godsdiensbeoefening. Hierdie artikel wil vasstel watter pad die psalms ons wil laat inslaan, veral watter lig Psalm 1 en 2 op hierdie onderwerp werp. Gaan dit om kyk, beleef (soos in sing, ritueel beoefen, bid, kreatief met die Bybel omgaan) of om luister? Watter rol speel die verstand en verstaan? Wat is die implikasies daarvan - dus, wat moet volgens Psalm 1 en 2 die beheersende funksie in 'n mens se geloof en lewe wees?

Veral die psalms gee 'n aanduiding van wat Bybelse spiritualiteit is. Die rede waarom veral na Psalm 1 en 2 gekyk word, is omdat Psalm 1 die ware lewenspad aanwys, dit wil sê die manier waarop 'n mens moet lewe; daarby is Psalm 1 verder nie maar net een van die psalms nie, maar dit beklee 'n besondere plek. Psalm 1 is saam met Psalm 2 'n inleiding tot die Psalms en dus 'n rigsnoer vir hoe 'n mens met die psalms moet omgaan en hulle moet verstaan. Om hierdie plek en betekenis van Psalm 1 en 2 as inleiding tot die Psalms in te sien, is uiters belangrik. Hierdie insig gee perspektief op die geheel van die psalms en stel 'n mens in staat om die onderskeie psalms binne hulle goter verband te lees.

Psalm 1 en 2 is 'n oproep om volkome te vertrou in God en sy regering van hierdie wêreld vol stryd en vyandskap. Daar is oorwinningskrag vir wie volhou om God te dien, selfs al lyk dit soms of die goddeloses beter daaraan toe is as die regverdiges. 'n Mens moet heeltemal en vrywillig inval by God se wil soos dit in sy Tora, sy Wet (Woord) gegee is. Wie dit doen, vind ware vreugde en sinvolheid. Dit geld selfs in die harde lewenstryd waarvan baie psalmdigters getuig. Die Tora is nie net 'n voorwerp van studie nie, maar is ook ' $n$ mens se lewens- en kragbron. Dit laat 'n mens bestand wees teen die storms en droogtes van die lewe en maak jou werklik voorspoedig (Ps. 1:3-4). Ware en onverganklike lewe lê daarin om 'n regverdige te wees en onder God se sorg te wees (Ps. 1:6). Daarom kan die kleiner bundels van die Psalms (Ps. 1-41, 42-72, 73-89, 90-106, 105-150) met lofsegging eindig, selfs al is die omstandighede somber (vgl. Ps. 41). Dit is die rede waarom die digter van Psalm 42/43 in 'n reddelose situasie homself kan vermaan om op God te bly vertrou en daarom kan Psalm 1 en 2 net voor Psalm 3 staan wat oor die harde onreg van die lewe handel. By God alleen vind 'n mens uiteindelik rus oor hierdie probleem (Ps. 73). Die regverdige is nie 'n volmaakte mens wat net teenoor 
die goddelose staan nie, maar iemand wat self die hand in eie boesem moet steek (Ps. 104:34-35; 139:21-24).

Psalm 1 plaas die Tora van die Here (in die betekenis van die Wet en ook in die wyer betekenis van die Woord) op die allesbeheersende voorgrond. Hiermee kom die saak van luister sterk na vore - dit wil sê, luister na én gehoor gee aan die Tora. Daar sal aangetoon word watter perspektief hierdie plasing van Tora in Psalm 1 op die hele saak van godsdiensbeoefening en ook op spiritualiteit gee. Spiritualiteit het hier die wye betekenis van hoe 'n mens jou godsdiens benader en uitleef - 'n spiritualiteit wat nie tot die sogenaamde geestelike aspek van 'n mens se lewe beperk is en wat losstaan van die stoflike lewe nie.

\section{Pluralisme}

Volgens Schneiders $(2002: 134,135)$ is daar teologiese pluralisme in die Bybel. Die Nuwe Testament bied 'n verskeidenheid begrippe aan oor God, Christus, die kerk, die wêreld, moraliteit, verlossing en eskatologie. Hierdie teologiese verskeidenheid is nie slegs die gevolg van besondere historiese en kulturele omstandighede (settings) nie, maar is die gevolg van die verskillende maniere waarop God in verskillende omstandighede ervaar word. Die verskil in die spiritualiteite in die Skrif regverdig volgens Schneiders die verskillende spiritualiteite onder Christene en is dialogies (deuteronomisties), Christosentries (Paulus), kontemplatief (Johannes), ekklesiasties (die Pastorale Briewe) en apokalipties (Openbaring) van aard.

Bybelse spiritualiteit is volgens Schneiders $(2002: 136,140,141)$ 'n transformatiewe proses van persoonlike en kommunale betrokkenheid by die Bybelse teks. Die teks moet in sy eie taal praat. Bybelgedeeltes moet gelees en herlees word. Dan moet daartoe oorgegaan word om God in gebed te beantwoord. Die gebed blom dan ten volle uit in 'n beeldlose en woordlose eenheid met God in die Gees. Die basis van Bybelse spiritualiteit is die teks self, verinnerlik (interiorised) deur die persoon wat lees in terme van sy of haar werklike ervaring en deur dialoog tussen die antieke teks en hierdie leser, beliggaam in die beleefde ervaring van die huidige Christengemeenskap. 


\section{Problematiek van die videosfeer en tegnologiese sfeer}

Die relevansie van die tema van hierdie artikel blyk uit die herhaalde aanklagte in die media teen die kerk se benadering van godsdiensbelewing. Die relevansie blyk ook uit skrywes oor aktuele sake, soos dié van Rossouw en Jordaan in 'n dagblad (Beeld).

Rossouw en Jordaan maak belangrike stellings oor die videosfeer en oor die tegnologiese era waarin ons leef. Rossouw (2004a:20; 2004b:11; 2004c:15) skryf oor "die dilemma van God in die videosfeer" en sê dat God as die "Stil Onsigbare" nog verder uit ons beleweniswêreld verdryf word deur die moderne videosfeer se eis van sigbaarheid en onmiddellike teenwoordigheid. Hierdie eis veroorsaak dat God deur niemand meer raakgesien word nie. Jordaan (2004a:8) beweer dat kerklike teologie in 'n sekere sin subtiel medeverantwoordelik is hiervoor, deur God te verplaas na die "hemelsfeer". Hy sê dat 'n mens in die postmoderne idioom anders oor God kan dink, deur byvoorbeeld verbeeldingryk om te gaan met die Skrifbelofte dat die koninkryk reeds "binne en tussen ons is" en dat God daagliks "sigbaar" gemaak word in die klein besonderhede van ons bestaan.

Rossouw (2004b:11) oordeel dat belewenis die VSA na geloof in die supermens lei, maar Europa na leegheid en soeke. Hy (Rossouw, 2004c:15) meen tradisies (tekste) moet herlees word vir nuwe insig in die tegniese wêreld. Tegniese gevorderdheid verskraal nie noodwendig die behoefte aan religie nie, net soos wat tegniese beperktheid ook bevorderlik is vir religie. Die tegniek gee die VSA die illusie van beheer oor sy bestemming ("wat vinnig besig is om van die een morsige supertegnologiese oorlog na die volgende te verdamp"). Daarteenoor het Europa al sedert die Nywerheidsomwenteling en veral deur die Tweede Wêreldoorlog, 'n ander belewenis deurgemaak. Europa het beweeg van 'n geloof, wat deur tegniek in beheer van sy eie bestemming is, na 'n geloof wat weens sy tegniek beheer oor sy bestemming verloor. Ons kan in 'n wêreld van toenemende tegniese gesofistikeerdheid nie meer op dieselfde manier as voorheen glo nie. Dit is 'n eindelose verhaal van nuwe patrone wat in die wisselwerking tussen mens, tegniek en omstandighede vorm.

Volgens Jordaan (2004b:10) bied spiritualiteit in die kerk 'n enorme uitdaging. Daar word deesdae toenemend gepraat en geskryf oor spiritualiteit as 'n erg verwaarloosde bestanddeel van die menslike mondering. Talle godsdienstige mense ervaar toenemend ' $n$ soort 
verstarring in hul godsdienstigheid. Hulle beleef godsdiens as ritualisties, gegrond op kerklik gesanksioneerde morele reëls wat jou goed en soet moet hou, maar nie die verbeelding aangryp nie en jou nie met 'n diep lewensblydskap vervul nie. Wat die moderne mens ten diepste begeer, is ' $n$ bietjie meer mistiek en verwondering en minder voorskrifgeloof. Jordaan meen, in aansluiting by die twintigste-eeuse Katolieke teoloog, Karl Rahner, dat die herontwaking van mistiek onstuitbaar is.

So 'n spirituele kern word volgens Jordaan ook in wetenskaplike ondersoeke, binne die raamwerk van die kwantumfisika, aangedui. Dit lyk of die mens neurologies "bedraad" is vir lewensverrykende spirituele belewenisse wat ook helend en kreatief kan wees; dat daar selfs 'n "God-kol" in die brein is wat 'n mens van sy teenwoordigheid bewus maak en 'n nuwe en deurstralende lewensblydskap voortbring (vgl. ook Jordaan, 2005:14).

\section{Innerlike belewing en kreatiwiteit/transformasie}

De Villiers (1999:416, 420-423) sê ware innerlike belewing is kreatief, transformeer 'n mens en bemagtig jou om deel te hê aan transformasie. In die psalms is daar baie verwysings na meditasie, refleksie en kontemplasie. Hoewel gebed op sigself belangrik is, moet dit egter aangevul word deur hierdie proses van meditasie.

De Villiers (1999:423-426) beweer verder dat, hoewel die psalms nuttige bronne en modelle vir kontemporêre spiritualiteit is, kreatiwiteit en vindingrykheid nodig is om sinvol aan moderne geloofservarings uitdrukking te gee. Hy sê geleerdes beweer dat die inhoud van die Bybel belangriker is as die geskrewe vorm en hulle verwys dan na feministiese spiritualiteite waarvolgens daar 'n geleidelike en progressiewe patriargalisasie van die kerk plaasgevind het. Voorts is daar 'n negatiewe waardering van die eksperimentele benadering, onder andere die histories kritiese benadering.

'n Kreatiewe lees van die teks help volgens De Villiers om beter te verstaan hoe Jesus die Psalms gelees het. Wanneer die evangelieskrywers die dood en opstanding van Jesus in terme van Psalm 22 verduidelik, verstaan hulle dit so, dat Hy die klaging van dié wat ly opneem en in die lyding deel.

De Villiers (1999:431, 432) meen dat hoewel die Bybelse teks 'n defekte spiritualiteit korrigeer, die teenoorgestelde ook waar is. Die dissipline van spiritualiteit maak ons gevoelig vir die onvoltooide en 
selfs hoogs problematiese spiritualiteit van bepaalde Bybelse tekste. Hy verwys na geweld, uitbuiting en onderdrukking van mense op die rand van die samelewing, soos vroue, slawe en teenstanders (Keck, 1978:42).

Hy meen dat daar in die bespreking van spiritualiteit ernstige aandag gegee moet word aan die gewelddadige aard van baie psalms. Christene moet bemagtig word om hierdie beswarende (burdensome) gedeeltes te kan hanteer. Baie antwoorde is volgens hom gegee om hierdie probleme die hoof te bied. Sommiges sê dat hierdie wraaksugtige gedeeltes gekorrigeer word deur ander gedeeltes van die Bybel of die Nuwe Testament (vgl. Westermann, 1989:300), of dat die spiritualiteite in die Bybel verstaan moet word in terme van hulle eie tyd, verbande en teologie, of dat hierdie gedeeltes bepaalde psigologiese prosesse verteenwoordig (bv. Craven, 1991:49-52).

Ons kan nog die volgende byvoeg: Janowski $(2003: 43,65)$ praat in aansluiting by Hossfeldt en Zenger van die realisme en onvervalste spiritualiteit van die psalms. Murphy $(1993: 55,56)$ sê dat die uitings van woede die demoniese wat daar in elke mens se hart is, aandui. Wraakgevoelens word deur elke mens ervaar. Wanneer hulle in die gebed gehoor word, dien hulle daartoe om ons eie gevoelens te belig en ons aan te kla van ons eie mislukking en wraaksug. Crenshaw $(2001: 67,68)$ stel dat, hoewel die gebede om vergelding of wraak (vengeance) verstaanbaar is, dit nie teologies geregverdig kan word nie, ongeag of dit gebid word uit besorgdheid oor die slagoffers van onreg, of ter verdediging van die eer van God. Ballard (1999:94) wys op die ooreenkoms met ou Nabye-Oosterse beskouings, maar ook op die verskil: kensketsende gebruike van die Goddelike strydermotief in die psalms, is Jahwe as die afwesige Goddelike stryder (warrior) en as 'n Goddelike vredemaker.

De Villiers (1999:432, 433) beweer voorts dat sodra ontoereikendhede in tekste aangedui is, 'n andersoortige spiritualiteit ontwikkel en gebou kan word. Dit dra dan by tot 'n belangrike spirituele transformasie wat binne die gelowige plaasvind: om nie alleen haar of sy afhanklikheid van die teks te besef nie, maar ook 'n onafhanklikheid. Hy sê dit kan alleen gedoen word waar gelowiges verantwoordelikheid neem vir hulle lewens in 'n oop en kreatiewe dialoog met spiritualiteit in die Bybelse teks. De Villiers beweer verder dat postmodernisme as 'n leesstrategie verskille en teenstellings waardeer (celebrate) en openbaar hoe monolitiese en metafisiese konstruksies deur 'n modernistiese paradigma op tekste afgedruk is. Daar is volgens hom baie gesigte van spiritualiteit in die 
psalms en elkeen vertoon 'n onderskeie trek. Die uitdaging is om hulle te herken en te evalueer in terme van moderne spiritualiteite.

\section{Teologiese refleksie of belewing as bron?}

Firth $(1999: 452,453)$ sê die volgende in verband met getuienispsalms (Ps. 30, 34, 40, 73, 116, 138): Getuienis bied nie 'n manier van rasionele refleksie in die sin dat verskillende antwoorde wat gegee sou kon word, aan analise onderwerp kan word nie. In plaas daarvan bied getuienis ' $n$ manier vir hoorders en lesers van hierdie tekste om as 't ware deur ' $n$ venster na hulle eie belewing te kyk - 'n venster afkomstig van die refleksies van hierdie digters. Hulle plaas hulle in die plek van medeleerlinge, maar as leerlinge wie se belewing aan hulle ' $n$ basis verskaf om moontlike resultate aan die hand te doen aan dié wat die getuienis hoor.

Firth sê verder dat waar direktiewe taal gebruik word, die grond daarvoor nie teologiese refleksie is nie, maar belewing; ons het dus te doen met 'n belewing-gebaseerde teologie, waarin belewing die refleksie wat daarop volg, vorm. Dit staan volgens hom in sterk teenstelling tot psalms van waarneming (bv. Ps. 1, 37, 49 en ook die Tora-psalms) wat soortgelyke sake aanpak vanuit die perspektief van die deskundige, sodat die bestaande teologie die maniere waarop die belewing beoordeel word, bepaal. Deur albei hierdie modelle te behou, dui die redakteurs van die psalmbundel aan dat albei belangrik is en dat albei hulle plek het binne die onderrig wat hulle bied. Getuienis bly egter een van die belangrike maniere van onderrig, 'n manier wat die tradisionele vormkritiese grense oorskrei.

Endres (2002:143) sê: "The Psalms invite various levels of interpretation. Both expressive and formative, they not only mirror reality but also tutor persons in the spiritual life."

In reaksie op die voorgaande stellings, moet wel daarop gewys word dat die psalms wel mense se belewing weergee, anders as die profete wat sê "So sê die Here". Andersyds word dit ook gedoen onder heerskappy en leiding van die Woord. Volgens Psalm 1 word die Woord "dag en nag oordink".

In die postmoderne tyd is Calvinisme in diskrediet, as te verstandelik, strak en emosieloos. Volgens Psalm 1 speel oordink van die Woord 'n baie belangrike rol. Tot nog toe was dit ook die geval in gereformeerde spiritualiteit, soos dit tot uiting kom in die lewensbenadering en lewenshouding, in inkleding van eredienste en ander samekomste, in prediking, ook kategismusprediking en ander 
lerende stof. Hierdie lerende aard het die gereformeerde kerke 'n invloed laat uitoefen buite verhouding tot hulle getalle. Verloor hulle dit, verloor hulle hulle stem. As godsdiensbeoefening in die algemeen aan die verstandelike aspek gaan inboet, gaan die kloof tussen godsdiens en wetenskap groter word, asook die dualisme tussen verstand en gevoel in die godsdiens. Die godsdiens gaan dan nog meer na die naïewe en private terrein verskuif word. Die "nuwe hervormers" beklemtoon wel die verstand, maar maak die fout om die verstand as maatstaf, in plaas van as middel, aan te wend.

\section{6. 'n Soeke na betekenis is onderwerp aan geregtigheid}

Teenoor die nadruk wat in ons tyd op identiteit geplaas word, plaas Brueggemann (2002:73, 74) die nadruk op geregtigheid en verantwoordelikheid. Dit doen hy vanuit sy nadruk op die Tora in die inleidende Psalm. 'n Mens kan sy benadering miskien soos volg verduidelik: die nadruk op identiteit laat 'n mens konsentreer op hoe jy verlos word, of hoe in jou geestelike en stoflike behoeftes voorsien kan word, of hoe jy 'n wenner kan wees, ensomeer. Die konsentrasie moet egter nie op jou identiteit wees nie, maar op met wie jy identifiseer. In baie psalms gaan dit om die nood van die armes en hulpeloses. Ons kan hier byvoeg dat Psalm 1 die individuele op die voorgrond plaas, maar dan die enkeling omring deur 'n groep, die regverdiges, die verbondskring. Dit is dus ' $n$ verbondsbenadering en vanuit hierdie geborge kring van verlossing is dit ' $n$ benadering van dankbaarheid, ' $n$ betrokkenheid by almal wat op enige manier in die nood is.

Brueggemann $(2002: 73,74)$ sê die psalms was vroeër sentraal vir 'n spiritualiteit wat individualisties en wêreldvreemd is, of wat toegespits is op 'n soeke na betekenis. In werklikheid word die psalms egter daardeur gekenmerk dat hulle "betekenis" aan "geregtigheid" onderwerp. Die psalms dring gereeld aan op genoegsame gelykheid, mag en vryheid om die eie lewe menslik te lewe. Wanneer ons hierdie psalms bid, in die gemeenskap of privaat, is ons omring deur 'n wolk van getuies wat op ons gebede reken. Die psalms gee uiting aan die hoop vir 'n nuwe ekwilibrium in die koninkryk van reg en geregtigheid. Brueggemann (2002:72) benadruk ook dat ons in die psalms nie geweldsdade het nie, maar geweldstaal.

Brueggemann (2002:8) deel die psalms in drie groepe in, naamlik eerstens psalms van oriëntasie, van dankbaarheid in tye van voorspoed; tweedens psalms van disoriëntasie, wat uiting gee aan woede, verwyt, selfbejammering en haat voortspruitend uit tye van 
angs, vervreemding, lyding en dood; en derdens psalms van heroriëntasie, oor wanneer 'n mens onverwags oorweldig word deur die nuwe gawes van God en daar vreugde deur wanhoop breek. Die beweging tussen die tye is transformeel, nie ontwikkelend nie, nooit "natuurlik" nie, altyd in pyn en verrassing.

Verder sê Brueggemann (2002:26, 30) dat ernstige religieuse gebruik van die klaaglied minimaal is, aangesien ons glo dat geloof nie beteken om negatiwiteit te erken en te omhels nie. Hierdie psalms gee uiting aan dit wat deur die dominante eise van die samelewing gesensor en in toom gehou is - daarom neig hulle na hiperbool, aanskoulikheid en stellings wat "ordentlike" religieuse sensitiwiteite skok. Hulle word gegiet in volgehoue en rigiede vorms wat vir die gemeenskap verstaanbaar is.

Brueggemann se opmerkings geld veral kerke se handleidings vir Skriflesing. In die gereformeerde liturgie word oorwegend psalms gesing. Dit lei daartoe dat klaaggedeeltes ook in ' $n$ mindere of meerdere mate ingesluit word.

\section{Psalm 1: 'n leerskool/onderrig in die een norm}

Die ballingskap het weinig geleentheid vir offerandes gebied. Wat die ballinge wel kon doen, was saamkom vir onderlinge gemeenskap en om na die Tora te luister. In Psalm 1 kom seremoniële funksies en daarmee ook die funksie van kyk, glad nie ter sprake nie. Die klemtoon val hier op die Tora (Wet/Woord) van die Here. Ook die gemeenskap van die gelowiges kom ter sprake: "vergadering van die regverdiges" (vers 5).

Crenshaw (2001:57) sê die aard van die oortredings in die boetepsalms bly duister, moontlik om die psalm se beroep op almal wat vergewing soek, te versterk. Ons kan hier byvoeg dat sondebelydenis, boete en sonde nie direk in Psalm 1 ter sprake kom nie. Dit beteken egter nie dat sondebesef geen of 'n geringe rol speel nie. Inteendeel, lyding kom byvoorbeeld ook nie in Psalm 1 en 2 ter sprake nie, maar speel tog 'n baie belangrike rol in die psalms. Die fokus is egter op die positiewe aspek: die Tora as lewegewende faktor en bron van blydskap. Die Wet en Woord maak nie dood nie, maar lewendig (anders as in Jes. 40:6-7, maar wel soos wat volg in vers 8). Die ballingskap, gevolg van Israel se ontrou aan die Wet/Woord, soos verkondig deur die profete, het nie die laaste woord nie. Die Wet/Woord is 'n bron van lewe en vreugde vir dié wat dit van harte kies. Net soos Jesaja 40 begin die psalms nie deur Israel tot bekering op te roep nie, maar dit begin met die koms van 
God na sy volk toe. Hy kom in sy Woord, as 'n verlossende Woord, met Homself betrokke by die pad van sy volk, die regverdiges. Hy ken die pad van die regverdige, lei hom op daardie pad en sorg vir hom op daardie pad.

Die psalms is nie oordadig in sondebelydenis nie, inteendeel, in die geheel gesien kom sondebelydenis nie dikwels voor nie. Woordverkondigers moet ook nie oordadig daarin wees nie. Dit lei maklik tot oppervlakkige en veroordelende prediking wat 'n optelsom van sondes maak, maar nie die diepte van ons sondigheid raakboor nie.

Weliswaar loop die Ou Testament nie te koop met die sonde nie. In die agtergrond, onuitgesproke maar beheersend, is daar egter dit waarmee die menslike geskiedenis volgens Genesis begin: die sondige gevallenheid van die mens. Dit is nie daar as iets verlammends in die sin dat 'n mens kan voel dat jy te sleg is en niks kan doen nie. Dit laat 'n mens egter jou diepe sondigheid besef, maar laat jou nie bloot teen uiterlike sondedade vaskyk en dit veroordeel nie. Jy neem jou toevlug na God in die besef dat jy slegs uit sy genade leef. Dit maak dat 'n mens nie te veel van jouself dink nie en ook nie op ander mense neersien nie. 'n Mens wil dan uit dankbaarheid jou verantwoordelikheid nakom en tot eer van God lewe. Hiermee is 'n paar belangrike kenmerke van Bybelse, en dus ook gereformeerde spiritualiteit, aangeraak.

Psalm 2 teken God as die eintlike Koning (vgl. ook die psalms oor God as koning), wat deur middel van die gewone koning regeer en wat tegelyk 'n ander Koning van veel groter gestalte in die toekoms in die vooruitsig stel. Hy is die magtige regeerder. Sy teenwoordigheid kom hindernisse te bowe.

Psalm 1 en 2, gelees as inleiding tot die psalms, verteenwoordig reeds 'n uitgangspunt oor hoe die psalms gelees moet word. Dit beteken egter nie dat die leser of hoorder self na willekeur 'n eie uitgangspunt kan hê nie. Inteendeel, Psalm 1 en 2 verbind die psalms met 'n uitgangspunt buite ' $n$ mens self, naamlik aan die Wet/Woord van die Here (Ps. 1:1). Die leser of hoorder moet daarvan afsien om, soos die goddeloses, sondaars, spotters (Ps. 1:1), sy eie kop te volg en moet die Wet/Woord "dag en nag oordink". 'n Mens moet dus jou hele denke, optrede en lewe daardeur laat bepaal. Daarmee boefen jy egter nie 'n wettiese godsdiens nie, nie 'n keuse onder dwang nie, maar een waarin 'n mens jou vreugde vind. Psalm 1 begin trouens met "goed gaan" en "vreugde" hê. 
Reindl (1981:337-338) sê Psalm 1 se plasing voorop in die Psalms wys dat die indiwiduele psalms nie meer in isolasie gelees wil word nie, maar binne die konteks van die hele psalmbundel (vgl. ook Loretz, 2002:14). Die psalms word nie meer by 'n bepaalde kultiese geleentheid gesing nie, maar word as Jahwe se Tora gelees, met ywer bestudeer en binne die konteks van die Tora as geheel bekyk en dus van sy situasiegebondenheid losgemaak. Die oorspronklike (voorballingskapse - JLH) Sitz in Leben verbleek (nie verdwyn nie!) voor die nuwe Sitz im Leben wat die psalms verkry het.

Die plasing van die Tora voorop, beklemtoon die psalms as bron van onderrig en lering eerder as van kultus of gebed (vgl. McCann, 1992:120). Kratz (1996:3) se bevinding dat die psalmbundel nie die "gesangboek van die na-ballingskapse tyd" is nie, stem hiermee ooreen. Seybold (1998:67, 68) stem saam met Tournay (1991:7, 230) dat die psalms nie bloot gebede en liedere bevat nie, maar ' $n$ dialogiese en liturgiese, dit wil sê 'n profetiese, aard het.

Ook Zenger (2000:430-435) oordeel dat die psalms nie 'n kultiese liedereboek is nie, maar 'n leerboek en instrument vir die heiliging van die alledaagse lewe maar ook vir die lewe buite die tempel en die sinagoge. Die psalms is self die heiligdom waarin God gesoek en geloof word en waarvandaan God se seën en redding uitgaan. Die tempel en tempelkultus word nie vervang nie, maar dit gaan om die ontmoeting met God wat ook en veral in en vanuit Jerusalem se tempel werk. Hy is Koning van Israel en van die hele wêreld.

Saam met Brueggemann (1993:29, 31, 32, 41) moet die woord of begrip kulties veel wyer verstaan word as wat Mowinckel dit verstaan het. Brueggemann sê kulties is "the matrix of symbolism by which the community continuously reasserts its identity and reconstructs its life". In hierdie sin is alle psalms kulties; hulle is die tekens van 'n noodsaaklike historiese regstelling van Israel se lewe in die Persiese of Hellenistiese omgewing. Tog was daar nie 'n algehele breuk in hulle lewensbenadering nie, maar kontinuïteit volgens Brueggemann.

Watter lig gee die psalms onder bespreking op die saak van voorskriftelikheid? Hulle sê ons het in ons lewe te doen met die Wet of wil van die Here. God vra onvoorwaardelike oorgawe aan sy wil. Die Bybelse godsdiens is egter nie ' $n$ wettiese godsdiens nie. Dit het te doen met vreugde en met voorspoed ('asjeree, happy). Die woord wet is nie 'n volledige weergawe van die Hebreeuse Tora, wat eintlik lering beteken, nie. Daarby praat Psalm 1 van die Wet "van die 
Here". Dit is nie 'n onpersoonlike Wet nie, maar bring 'n mens in 'n lewende, persoonlike verhouding met die Here.

\section{Belewing en kreatiwiteit, kragdadigheid, klaging en lofsegging in die psalms}

Watter lig gee die psalms onder bespreking op die saak van sien, verstaan, belewing en kreatiwiteit? Kan 'n mens kreatief met die psalms omgaan? En met die Wet en die Woord? Psalm 1 en 2 sê die omgekeerde is eintlik waar: die Wet en Woord gaan kreatief met jóú as leser of hoorder om. As jy as leser of hoorder intensief en voortdurend met die Wet/Woord omgaan, ontdek jy dat jy nie bloot die onderwerp is wat met die Woord besig is nie, maar die voorwerp met wie die Woord besig is. Die Woord werk in jou en verander jou lewe; jy word soos 'n lewenskragtige boom (Ps. 1:3). Jy kan nie passief bly nie, maar tree kragdadig op.

Die Psalms is 'n leerboek. Tog is die bundel vol uitings van gemoedstemmings en belewings. Dit moet egter beheers word deur die ken van, en die voortdurende omgang met die Wet/Woord van die Here en dit moet ook gepaard gaan met die daad, veral ten behoewe van die hulpeloses (vgl. veral Brueggemann). In Psalm 3150 is die regverdige gewoonlik die veronregte - hy is nie die een wat in beheer van sake is nie. Die regverdige is iemand wat hom in belewing, woord en daad volledig met die hulpeloses en veronregtes assosieer. Die leser of hoorder is nie net die een namens wie die digter praat nie, maar ook die een teen wie die digter hom rig. Soos wat die leser of hoorder homself by die intensiewe en voortdurende omgang met die Wet/Woord ontdek as die voorwerp en nie die onderwerp nie, so ontdek hy homself as die aangesproke vyand (vgl. Sheppard,1991:64, 69, 73) volgens wie die hoorder, die veronregter, in die gehoor is en die digter of spreker sy klag hoorbaar in die openbaar stel.

Ons is woordwesens en veral Woordwesens (vgl. Brueggemann). Die lewe bestaan uit luister en verwoord of antwoord, in hierdie volgorde. Dit sien ons reeds by babatjies. Psalm 1 en 2 laat sien dat verwoord en antwoord met luister na die Woord begin. Vanaf Psalm 3 is dit verwoord of antwoord. Psalm 1 en 2 laat sien dat dit ook daarom gaan dat 'n mens jou verantwoord, naamlik teenoor die wil van die Here, soos uitgedruk in sy Wet/Woord en sy pad met jou. Dit hang ten nouste saam met sy pad met die wêreld, met hoe Hy sy wil deurvoer, hoe $\mathrm{Hy}$ in die gebeurtenisse en deur sy gesalfde koning die oorwinning oor vyandige magte behaal. 
Die beantwoording begin met klaging, die klaaglied. Dit is die mees fundamentele uitdrukkingsvorm van die menslike gemoedstemming in die psalms. Die meeste ander uitdrukkingsvorms sluit hierby aan. Dit begin dus by 'n mens se belewing van 'n stukkende wêreld - 'n wêreld waarin 'n mens vyandskap en onreg beleef. Hierin neem die regverdige sy toevlug na God deur sy hart daaroor by God oop te maak oor hoe hy dit beleef en tot rus kom deur op God te vertrou.

Psalm 1 en 2 begin nie met klaging nie, maar met vreugde en vertroue. By vertroue word daar veral 'n beroep op 'n mens se persoonlike vertroue gedoen. Jy kan nie bloot staatmaak op die feit dat jy tot die volk van die Here behoort en alles sonder meer vir jou sal reg uitwerk nie. Met Psalm 1 vooraan die Psalms, word die mens as enkeling (indiwidualiteit) en sy persoonlike verantwoordelikheid voorop gestel, maar ook as iemand wat optree binne die gemeenskap van regverdiges (kollektiwiteit) en wat dus 'n verantwoordelikheid teenoor die samelewing het.

Dit gaan om vertroue in verband met sowel stoflike as geestelike dinge. Die Ou Testament bevat nie 'n bloot geestelike spiritualiteit nie. Hiervan getuig die stelling in Psalm 1: "Dit gaan goed met ..." wat 'n heel konkrete betekenis het, nie net 'n geestelike betekenis soos die 1953-vertaling "welgeluksalig" mag impliseer nie (vgl. ook Ps. 127). Die res van Psalm 1 wat van voorspoed praat, bevestig hierdie konkrete betekenis, so ook die konkrete inhoud wat seën gewoonlik in die Ou Testament het. (Vgl. byvoorbeeld Ps. 85:9, 1113: "Ek wil luister na wat God die Here sê, want sy Woord bring vrede vir sy volk, vir dié wat Hom getrou dien ... Liefde en trou sal mekaar ontmoet, geregtigheid en vrede sal mekaar omhels; trou sal uit die aarde uit opspruit, geregtigheid sal uit die hemel uit afkom. Die Here sal voorspoed skenk en ons land sal sy oes gee".)

Die hele mens is van God afhanklik. Vlees (basar) en gees (ruag) is albei nietig (Ps. 78:39; vgl. ook Rom. 8). Net soos daar geestelike daadkrag vereis word, so word ook liggaamlike en stoflike daadkrag vereis. Selfs tegnologie het 'n plek in Bybelse spiritualiteit. Die psalmdigter loof God omdat Hy hom leer om die boog te span en oorlog te voer (Ps. 144:1).

Om waarlik te lewe vra dus volgens die psalms dat 'n mens lees, luister, lewe, verander en gemeenskap beoefen met God en sy gelowiges. Psalm 1 stel 'n objektiewe maatstaf om godsdienstig in betrokkenheid te lewe - individueel persoonlik betrokke asook in gemeenskap met ander. Dit vra van die leser die volgende: 
- $\quad$ om te lees (en jou verstand in te span);

- om te luister (aangespreek te word; die voorwerp van die Woord te word);

- $\quad$ om daarmee besig te bly (dit "dag en nag te oordink"; nie net te lees om antwoorde vir sake te vind en die Wet/Woord dan as leesstof opsy te sit nie);

- $\quad$ om die Woord met jou te laat besig wees, in en deur jou te laat werk: jou idees, emosies en ingesteldheid daardeur te laat lei, te laat verander (soos wat 'n boom oorgeplant word om by waterstrome te staan);

- $\quad$ om nie jou eie innerlike gedagtes of gevoelens te regverdig of teuelloos tot uiting te laat kom nie. Dit beteken dus dat 'n mens die Wet/Woord "transformerend", reformerend met jou moet laat besig wees. Ware godsdienstige lewe sluit dus belewing en kreatiwiteit in hierdie betekenis en hierdie atmosfeer in.

Dit gaan dus veral om Bybelstudie en nie om uiting aan 'n mens se binneste te gee in gebede of getuienis nie. Vir so iets is daar plek, maar 'n ondergeskikte plek. Dit gaan in die Psalms om studie, mits dit is om die Here te ken. Dit beteken nie maar om die Here te ken as 'n voorwerp van jou kennis oor Wie jy meer en meer weet, soos oor die natuur of ander sake nie. Dit gaan daaroor om deur Hom in die Skrifgedeelte geleer te word en te besef dat Hy jou ken. Hierdie ken is nie bloot dat Hy van jou weet nie, maar dat Hy 'n verhouding met jou beoefen, ook 'n verhouding met die kring van gelowiges, en dat Hy vir jou sorg (vgl. by Ps. 1 ook Ps. 16:5-8, 11 - hoe die Here 'n mens "leer" om blydskap te hê).

Verder leer Psalm 1 dat die lewe nie 'n bereikte bestemming is nie, nie 'n afgehandelde situasie met die laaste woord nie, maar 'n pad. Die pad het moontlikhede vorentoe wat in die hand van God gelaat kan word. Die Here "ken" hierdie pad, Hy sorg vir die regverdige op hierdie pad (Ps. 1:6).

Die Psalmbundel werk op na lof toe (Ps. 146-150 en elke onderdeel van die Psalms: $1-41 ;$ 42-72; 73-89; 90-106; 107-150). Die grond vir hierdie lof is 'n lewe volgens die Wet/Woord van die Here. Dit raak sake soos omgang met Hom en die naaste, byvoorbeeld in gemeenskaplike lofsang. Verder raak dit die verbond, die koninkryk wat groter is as Israel, wat oopstaan vir wie by Hom skuil, selfs die vyande (Ps. 2:12). Psalm 1 en 2 is 'n korrektief op die keuse van die goddeloses en die opstandige optrede van die nasies; maar ook op die gesindheid van klaging. In elke kleiner bundel van die Psalms 
word met lof geëindig en hierdie lof word tot 'n klimaks gevoer aan die einde van die bundel in geheel. Lof is ook 'n uiting van verwondering oor God in sy grootheid en sy verrykende verhouding met die mens. Dit kom treffend tot uiting in Psalm 8 oor die grootheid van God se skepping en die nietigheid van die mens en oor hoe God nogtans die mens in 'n heersersposisie plaas - as skepsel in God se diens. Die digter begin en eindig deur God te loof.

\section{Spiritualiteit en vyandskap volgens die psalms}

Ware Bybelse spiritualiteit het ook veral te doen met hoe 'n mens vyande of vyandskap hanteer. Die vraag is veral: Wat van die vyandskap wat die psalmdigters self teenoor vyande betoon? NuweTestamentiese gelowiges vind dit 'n groot probleem en iets wat moeilik gerym kan word met Jesus se gesindheid en sy eis om selfs jou vyande lief te hê. Ek gaan net kortliks hierop in.

Die Nuwe Testament verkondig dat die Woord mens geword het, dat $\mathrm{Hy}$ in Jesus Christus konkrete, sigbare gestalte kom aanneem het (Joh. 1). Christus het sy Heilige Gees gegee om gelowiges in die waarheid te lei en in hulle te woon. So is vervul dat God 'n nuwe verbond met sy volk sou sluit waarin die Wet in hulle harte geskrywe word (Jer. 31:31-33). Christus self het benadruk dat Hy nie gekom het om die Wet en die profete te ontbind nie, maar om hulle hulle volle betekenis te laat kry (Matt. 5:17).

Psalm 1 en 2 gee die volgende lig op spiritualiteit en vyandskap: Psalm 1 is 'n oproep om te leef uit vertroue op God se regverdige bestier in hierdie wêreld vol goddeloosheid, lyding en onreg. God roep mense tot verantwoording en $\mathrm{Hy}$ staan die regverdige of gelowige by op sy lewenspad. In Psalm 1 word die gelowige aangeraai om lyding en onreg, waarvan so baie psalms praat, asook die hele lewe en alle gebeurtenisse, uit 'n ander hoek te benader. 'n Mens moet afsien van die heel menslike benadering om jou in hierdie stukkende wêreld as die brandpunt van lyding en veronregting te beskou of te ervaar. Psalm 1 is 'n korrektief of ' $n$ reformering of transformering op 'n mens se lewensbenadering.

'n Mens word uitgenooi om jou in die Wet/Woord van die Here te spieël oor hoe jy die beeld van die regverdige vertoon. Jy moet uit die middelpunt van jou gedagtes en benadering tree en die Wet/Woord die middelpunt maak. 'n Mens se aandag moet "dag en nag" daaraan gewy word. Jy moet jou gedagtes, belangstelling en lewe daardeur laat bepaal, sodat jy soos 'n oorgeplante boom word, ' $n$ boom by lewegewende waterstrome. Jy moet persoonlik, as 
enkeling, hierdie keuse maak en dit as enkeling uitvoer, maar tog nie in isolasie nie, maar as deel van die gemeenskap van gelowiges. Jy moet vertrou op die regverdigheid van God en sy regering van die wêreld, wat trouens groter is as jy self en jou belange. God straf die onreg (Ps. 2:5). Daar is egter ook 'n oop deur na Hom toe vir almal wat by Hom skuiling soek, ook wie nog sy vyande is (Ps. 2:12).

God sorg ruim vir die gelowige (Ps. 1:1-3, 6), maar dit gaan nie bloot om die gelowige nie, dit gaan om die heerskappy (koninkryk) van God (Ps. 2). Dit is soos met die gewone koning. Hy regeer in God se naam (Ps. 2:7), maar tog as 'n skadubeeld van 'n groter koning (Messias). Hy is in diens van die koninkryk van God. So is die gelowige ook in die eerste plek iemand wat in diens is - in God se koninkryksdiens. In hierdie koninkryksdiens is hy 'n stryder teen die onreg en die boosheid in hierdie wêreld. Hy word ook deur die Wet/Woord tot die besef gebring dat mense in die boosheid se mag is. Daar word ook 'n begeerte in die gelowige gevoed om sulke persone op die pad van bekering na God en sy Wet/Woord toe te lei, sodat die boosheid in sy kern oorwin word.

In Christus word die mag, regverdigheid en die liefde van God dus so geopenbaar dat ons die regverdigheid van God teenoor die vyande aan Hom kan oorlaat en dat ons sy liefde vir ons, wat ook sy vyande is, kan beantwoord met liefde, wat daarin uitkom dat ons ons vyande tot bekering probeer roep.

\section{Samevatting en gevolgtrekking}

Op die vraag of dit in die Bybelse godsdiens gaan om kyk - wat insluit om seremoniële pligplegings na te kom - beleef of luister, kan in die lig van bogaande bespreking die volgende geantwoord word: Konsentrasie op kyk lei tot oppervlakkige omgang met God se openbaring. Luister lei sterker tot nadenke en verdieping. Dit sien 'n mens duidelik deur die programme van die televisie en die radio in die algemeen te vergelyk. Die Bybelse godsdiens het egter nie bloot te doen met watter sintuie 'n mens gebruik nie, en ook nie net met sang, liturgie en innerlike gevoelsverryking, of verstandelike verryking nie, maar met 'n verhoudingsaak. 'n Mens moet luisterend en met betrokkenheid omgaan met die Wet/Woord, met God (deur die Wet/Woord na te kom) en met jou naaste (deur regverdiges daadwerklik lief te hê, veral die hulpeloses). 'n Mens se persoonlike verhouding met God en jou naaste en daarmee saam jou persoonlike verantwoordelikheid, staan voorop, maar tog as deel van die gemeenskap van die gelowiges of regverdiges. Verder moet 
'n mens korrektief en reformerend omgaan met jou benadering om jouself as middelpunt te beskou. Jy moet jouself eerder sien in diens van die belange van God se koninkryk, wat groter is as jou eie belange en wat ook meer mense se belange op die oog het as bloot jou eie.

Belewing en kreatiwiteit het 'n plek, maar geheel en al onder heerskappy van die Wet/Woord as die enigste norm. In hierdie opsig is daar vir die psalmdigters geen pluralisme nie. Psalm 1 laat die klem op onderrig val. 'n Mens bly op die lewenspad in die leerskool van God se Wet/Woord en onder sy persoonlike sorg. Hierdie leerskool volgens die enigste norm, word nie as 'n las of as voorskriftelik ervaar nie, maar as lewegewend en as 'n bron van vreugde. Dit rus op vertroue in God en op verwondering van God se pad met 'n mens.

Die kreatiewe mag waarvan Psalm 1 praat, is die Wet/Woord, nie menslike insette nie, selfs nie gebed nie. Die Wet/Woord werk korrektief, reformerend of transformerend in op 'n mens se selfgesentreerde benadering van voorspoed, lyding en onreg. Dit wek in ' $n$ mens vertroue op in God se regering in 'n stukkende wêreld en wek ook 'n bereidheid tot diensbaarheid in 'n koninkryk groter as jou eie belange. Die Wet/Woord laat die gelowige soos ' $n$ boom word wat by waterstrome geplant is en wat vrugte dra. Hy is voorspoedig in alles wat hy aanpak, want die Here "ken" die regverdige se pad en sorg vir hom. In nuwe situasies kan nuwe lig te voorskyn kom, maar dit gebeur deur verdieping in die Wet/Woord, soos dit deur die geskiedenis gewerk het en tot in die toekoms sal werk. 'n Mens moet in dialoog wees met die Wet/Woord van die Here en dus met die Here self - Hy wat die soewereine God is en wat vra dat 'n mens inskakel by sy Woord of wil.

Ware Bybelse spiritualiteit is nie net op die Wet/Woord en God gerig nie, maar ontstaan uit die Wet/Woord en God en word ook so gestimuleer en gevoed. Dit is hier waar ware kreatiwiteit lê en gesoek moet word.

In die Bybelse spiritualiteit is daar plek vir klaging voor God oor die lyding en onreg, maar dit loop uiteindelik uit op lof aan God, selfs wanneer daar nie direk uitkoms in sig is nie (vgl. die einde van Ps. 41 en die lofseggings waarmee elke kleiner bundel van die Psalms afgesluit word).

Bybelse spiritualiteit veronderstel 'n diepe sondebesef, wat soms tot openlike belydenis kom, maar waaroor nie geroem word nie. Dit 
gaan volgens Psalm 1 en 2 om luister (hoor), bedink én om gehoor te gee as herskepte en om in hierdie sin as kreatiewe en sodoende as regeerde te regeer, as dienaar, as iemand wat met dankbaarheid en vreugde diensbaar is op God se pad met jou in sy koninkryk. Dit alles toon hoe belangrik dit is vir Bybelse spiritualiteit is om die Psalms te lees en in die eredienste te sing.

\section{Geraadpleegde bronne}

BALLARD, H.W. Jr. 1999. The divine warrior motif in the Psalms. North Richland Hills: Bibal Press.

BONNER, G. 1983. St.Augustine of Hippo. (In Wakefield, G.S., ed. The Westminster dictionary of Christian spirituality. Philadelpia: Westminster Press. p. 33-34.)

BRUEGGEMANN, W. 1993. Response to James L. Mays "The question of context". (In McCann, J.C., ed., The shape and shaping of the Psalter. Sheffield: JSOT. p. 29-41.) (Journal for the Study of the Old Testament. Supplement.)

BRUEGGEMANN, W. 2002. Spirituality of the Psalms. Minneapolis: Fortress.

CRAVEN, T. 1991. The book of Psalms. Collegeville: Liturgical Press.

CRENSHAW, J.L. 2001. The Psalms: An Introduction. Grand Rapids: Eerdmans.

DE VILLIERS, P. 1999. The Psalms and spirituality. Old Testament Essays, 12(3):416-439.

ENDRES, J.C. 2002. Psalms and spirituality in the 21st century. Interpretation, 56(2):143-154.

FIRTH, D.G. 1999. Psalms of testimony. Old Testament Essays, 12(3):440-454.

JANOWSKI, B. 2003. Das Buch der unverfälschten Spiritualität. Zum neuen Psalmenkommentar von F.-L. Hossfeldt und E. Zenger. Biblische Zeitschrift, 47(1): 43-65.

JORDAAN, W. 2004a. Moderne videosfeer eis dat God sigbaar is. Van mens tot mens. Beeld: 10, Mei 12.

JORDAAN, W. 2004b. Spiritualiteit in kerk bied 'n enorme uitdaging. Van mens tot mens. Beeld: 10, Jun. 23.

JORDAAN, W. 2005. Mens het kapasiteit om spiritueel te wees. Van mens tot mens. Beeld: 10, Feb. 2.

KECK, L.E. 1978. The Bible in the pulpit. Nashville: Abingdon.

KRATZ, R.G. 1996. Die Tora Davids. Zeitschrift für Theologie und Kirche, 93:134.

LORETZ, O. 2002. Psalmstudien: Kolometrie, Strophik und Theologie ausgewählter Psalmen. Berlin: De Gruyter. (Beihefte ZAW, 309.)

McCANN, J.C. 1992. The Psalms as instruction. Interpretation, 46:117-128.

MURPHY, R.E. 1993. The Psalms are yours. New York: Paulist Press.

REINDL, J. 1981. Weisheitliche Bearbeitung von Psalmen: Ein Beitrag zum Verständnis der Sammlung des Psalters. (In Emerton, J.A., ed. Congress Volume. Vienna. 1980. Leiden: Brill. p. 333-356.) (Supplement to Vetus Testamentum, 32.)

ROSSOUW, J. 2004a. Die dilemma van God in die videosfeer. Glasoog. Beeld: 20, Mei 8. 
ROSSOUW, J. 2004b. Belewenis lei die VSA na geloof in die supermens, Europa na leegheid, soeke. Glasoog. Beeld: 11, Mei 22.

ROSSOUW, J. 2004c. Tradisies moet herlees word vir nuwe insig in die tegniese wêreld. Glasoog. Beeld: 15, Mei 29.

SCHNEIDERS, Sandra M. 2002. Biblical spirituality. Interpretation, 56(2):133142.

SEYBOLD, K. 1998. Studien zur Psalmenauslegung. Stuttgart: Kohlhammer.

SHEPPARD, G.T. 1991. "Enemies" and the politics op prayer in the book of Psalms. (In Jobling, D., Day, Peggy L. \& Sheppard, G.T., eds. The Bible and the politics of exegesis. Essays in Honour of Norman K. Gottwald on his sixty-fifth birhday. Cleveland: Pilgrim Press. p. 61-82.)

TOURNAY, R.J. 1991. Seeing and hearing God with the Psalms. Sheffield: JSOT. (Journal for the Study of the Old Testament. Supplement Series, 118.)

VAN DER LINDE, S. 1960. Mystiek. (In Grosheide, F.W. \& Van Itterzon, G.P., reds. Christelijke Encyclopedie. Kampen: Kok. p. 118-120.)

VAN DER LINDE, S. 1961. Spiritualiteit. (In Grosheide, F.W. \& Van Itterzon, G.P., reds. Christelijke Encyclopedie. Kampen: Kok. p. 234.)

WAKEFIELD, G.S. 1983. Spirituality. (In Wakefield, G.S., ed. The Westminster dictionary of Christian spirituality. Philadelpia: Westminster Press. p. 361363.)

WESTERMANN, C. 1989. The living Psalms. Edinburgh: Clark.

WIETHAUS, Ulrike. 1996. Spiritualität. (In Wiethaus, Fiedler K. \& Starke, E., eds. Evangelisches Kirchenlexicon. Internationale theologische Enzyklopädie. 4. Band: S-Z. Dritte Auflage. Göttingen: Vandenhoeck \& Ruprecht.)

ZENGER, E. 2000. Psalmenforschung nach Hermann Gunkel und Sigmund Mowinckel. (In Lemaire, A. \& Saebo, M., eds. Congress Volume Oslo 1998. Brill: Leiden. p. 399-435.) (Supplement to Vetus Testamentum, 80.)

\section{Kernbegrippe:}

kyk, beleef of luister

spiritualiteit in die Psalms

Psalm 1 en 2 en spiritualiteit

\section{Key concepts:}

look, experience or listen

Psalm 1 and 2 and spirituality

spirituality in the Psalms 